\title{
Prevalence of retinopathy of prematurity: an institutional cross-sectional study of preterm infants in Brazil
}

\author{
João B. Fortes Filho, ${ }^{1}$ Gabriela U. Eckert, ${ }^{2}$ Fabiana B. Valiatti, ${ }^{2}$ \\ Marlene C. da Costa, ${ }^{3}$ Pedro P. Bonomo, ${ }^{4}$ and Renato S. Procianoy ${ }^{5}$
}

Suggested citation Fortes Filho JB, Eckert GU, Valiatti FB, Costa MC, Bonomo PP, Procianoy RS. Prevalence of retinopathy of prematurity: an institutional cross-sectional study of preterm infants in Brazil. Rev Panam Salud Publica. 2009;26(3):216-20.

ABSTRACT Objective. Retinopathy of prematurity $(R O P)$ is the leading cause of childhood blindness in most developed countries. This study aimed to verify ROP prevalence among all very low birth weight (VLBW) preterm infants admitted to a level-3 teaching hospital in Porto Alegre, Rio Grande do Sul, Brazil.

Methods. Institutional cross-sectional study of 407 premature infants with birth weight $\leq 1500$ g or gestational age (GA) $\leq 32$ weeks between 2002 and 2007. All infants screened for ROP were examined after the fourth week of life and followed up until the 45th week of adjusted GA. ROP prevalence was estimated at a 95\% confidence level.

Results. Some degree of ROP in one or both eyes occurred in 25.5\% (104) of all screened infants, and severe ROP (threshold stage 3 or higher, requiring treatment to prevent vision loss, as per the criteria of the U.S.-based Multicenter Trial of Cryotherapy for Retinopathy of Prematurity, CRYO-ROP) occurred in 5.8\% (24). Based on the criteria of The International Classification for Retinopathy of Prematurity (ICROP, 1984/1987), the disease reached stages 1,2 , and 3 in $11.3 \%$ (46), 8.4\% (34), and 5.4\% (22), respectively. One infant developed the disease up to stage 4 (partial retinal detachment), and one progressed to stage 5 (complete retinal detachment, resulting in $0.2 \%$ overall prevalence for ROP-induced blindness).

Conclusions. Overall incidence of ROP in this institutional study (25.5\%) was comparable to international results from developed countries. A comprehensive countrywide survey on $R O P$ in Brazil is recommended to determine any regional differences in disease prevalence.

Key words Blindness, prevention \& control; retinopathy of prematurity, epidemiology; prevalence; Brazil.

1 Department of Ophthalmology, School of Medicine, Federal University of Rio Grande do Sul and Hospital de Clínicas de Porto Alegre, Porto Alegre, RS, Brazil. Send correspondence and reprint requests to: João B. Fortes Filho, Department of Ophthalmology, School of Medicine, Federal University of Rio Grande do Sul, Rua Ramiro Barcelos 2350, Porto Alegre, RS, 90035-903, Brazil; telephone: +55 51333347 96; fax: +55 51322292 92; e-mail: jbfortes@prorop.com.br

2 Department of Ophthalmology, Hospital de Clínicas de Porto Alegre, Porto Alegre, RS, Brazil.

3 Neonatal Intensive Care Unit, Hospital de Clínicas de Porto Alegre, Porto Alegre, RS, Brazil.

4 Department of Ophthalmology, Federal University of São Paulo, São Paulo, SP, Brazil.
Retinopathy of prematurity (ROP) is a blinding disease in children occurring most often among preterm newborns of low birth weight (BW) or low gestational age (GA) (time elapsed between first day of last normal menstrual period and day of delivery, expressed in complete weeks) (1). ROP is one of the most

\footnotetext{
5 Department of Pediatrics, Newborn Section, School of Medicine, Federal University of Rio Grande do Sul and Hospital de Clínicas de Porto Alegre, Porto Alegre, RS, Brazil.
}

important causes of treatable childhood blindness in industrialized countries and is becoming increasingly prevalent in middle-income Latin American countries such as Brazil $(2,3)$.

ROP is under constant epidemiological study around the world due to the higher survival rates of very low birth weight (VLBW) preterm infants (preterm neonates with BW $\leq 1500 \mathrm{~g}$ ), according to reports from many Latin American countries (4-6). This same situation seems 
to occur in Eastern Europe as well as in some Asian countries (e.g., India) once progress in science and technology has permitted improvement in neonatal care of preterm infants $(7,8)$.

In Brazil, it is estimated that each year about 15000 surviving preterm infants at risk for developing ROP require screening examinations for diagnosis. Without treatment, an average of 562 children from this at-risk population are expected to go blind each year, resulting in a high socioeconomic cost, especially for a disease that is both preventable and treatable (9). Brazilian guidelines for neonatal screening for ROP were established in October 2002, during the first ROP Workshop ( $1^{\circ}$ Workshop de Retinopatia da Prematuridade) in Rio de Janeiro. This national meeting aimed to increase understanding about the prevalence of this disease in Brazil and to lower the number of cases of ROP-induced blindness quickly through adequate prevention and, when necessary, treatment (provided early in the course of the disease). The published guidelines for ROP screening for most Brazilian regions call for ophthalmological examinations of all preterm infants with BW $\leq 1500 \mathrm{~g}$ or GA $\leq 32$ weeks, initiated between the fourth and sixth week of life. The guidelines also call for screening of neonates in critical clinical conditions (as determined by the attending neonatologist), including those outside the population deemed at risk for ROP (10).

In 2002, the Clinics Hospital of Porto Alegre (Hospital de Clínicas de Porto Alegre, HCPA), a level-3 teaching hospital at Federal University of Rio Grande do Sul in Porto Alegre, a city of 3 million in Brazil's southernmost state, Rio Grande do Sul, implemented a screening program for diagnosis of ROP based on the Brazilian national guidelines. This study aimed to determine the prevalence of ROP among 407 VLBW infants admitted to HCPA's Neonatal Intensive Care Unit (NICU) and screened for ROP.

\section{MATERIALS AND METHODS}

The current study was cross-sectional and based on institutional data from a cohort of 407 preterm infants prospectively followed from 4 to 6 weeks after birth to the end of the first year of life. The ROP diagnosis was based on a crosssectional search conducted during the 45th week of adjusted GA (chronological age reduced by number of weeks born before 40 weeks of gestation).

The study included all VLBW preterm infants admitted to HCPA between October 2002 and December 2007 who survived through the 45th week of adjusted GA (i.e., infants who died during hospitalization before the initial ophthalmological examination, and those who died before the 45th week of adjusted GA, were excluded). The VLBW group comprised infants with $\mathrm{BW} \leq 1500 \mathrm{~g}$ and, as per Brazilian guidelines for ROP screening, infants with BW >1500 g but with $\mathrm{GA} \leq 32$ weeks.

The main study outcomes were 1) occurrence of ROP in any of its five stages of development and 2) occurrence of severe ROP (requiring treatment to prevent vision loss) in one or both eyes during the observation period (from 4-6 weeks after birth through the 45th week of adjusted GA). The worst stage of ROP, in either eye, was recorded. The ROP was classified by location (on the retina) (zone 1-3), and severity (stage 1-5), according to the criteria of The International Classification of Retinopathy of Prematurity (ICROP, 1984/1987) (11, 12). Severe ROP was defined as ROP in stage 3 (threshold disease), 4, or 5. Threshold ROP was defined according to the criteria of the U.S.-based Multicenter Trial of Cryotherapy for Retinopathy of Prematurity (CRYO-ROP) (13) (five or more contiguous or eight cumulative clock hours (30-degree sectors) of stage 3 in either zone I or II with plus disease (dilation and tortuosity of the posterior retinal blood vessels)).

The 407 infants in the study cohort were divided into the following four patient groups: Group 1, the entire cohort of screened infants; Group 2, infants with BW $\leq 1000 \mathrm{~g}$; Group 3, infants with BW >1 000 and $\leq 1250$ g; and Group 4, all infants with BW >1 $250 \mathrm{~g}$. The absolute and relative frequencies of ROP were estimated with a $95 \%$ confidence interval (CI), and the mean and standard deviation (SD) were calculated for the continuous variables (BW and GA).

The sample size was determined according to data in the Brazilian scientific literature that estimate about $25-30 \%$ of VLBW premature infants will have some degree of ROP, requiring a minimum of 323 patients for estimating ROP prevalence with a $95 \% \mathrm{CI}$ and a maximum acceptable difference of $5 \%$ (14).

All examinations were performed at the HCPA NICU between October 2002 and December 2007. The infants were examined while hospitalized and as outpatients (after discharge) up to the 45th week of adjusted GA. The ophthalmological exam consisted of binocular indirect ophthalmoscopy with a 28-diopter lens (Nikon, Melville, NY, USA) and a lid speculum (Alfonso Eye Speculum, Storz ${ }^{\circledR}$, Bausch \& Lomb Inc., San Dimas, CA, USA). Pupils were dilated with 0.5 tropicamide and 2.5 phenylephrine eye drops applied one hour before the examination. All exams were performed by the lead author, an ophthalmologist qualified to conduct ROP screening. All patients diagnosed with threshold ROP were treated with laser photocoagulation. The ophthalmological examinations were initiated between the fourth and sixth weeks of life and were repeated weekly or biweekly, as per the Brazilian guidelines for ROP screening, until full vascularization of the retina reached zone 3 (the most peripheral temporal retinal zone), or until full remission of ROP after treatment.

The study protocol was approved by the HCPA Research Ethics Committee, under number 03-248.

\section{RESULTS}

Of all 407 patients screened for ROP, $232(57.0 \%)$ were female and $252(61.9 \%)$ were small for gestational age (SGA) ( $<10$ th percentile). Across the entire cohort, BW ranged from $505 \mathrm{~g}$ to $2000 \mathrm{~g}$, with a mean of $1205.5 \mathrm{~g}$ (SD, 277.4), and GA ranged from 24 to 37 weeks, with a mean of 30.3 weeks (SD, 2.2) (Table 1). Table 2 shows the prevalence of all stages of ROP, estimated at a $95 \% \mathrm{CI}$, in the four patient groups (classified by BW). Some degree of ROP was identified in 104 patients, or $25.5 \%$ of cases, and severe ROP occurred in $24(5.8 \%)$. The disease reached stage 1 in $11.3 \%$ of the patients (46), stage 2 in $8.4 \%$ (34), and [threshold] stage 3 in $5.4 \%$ (22). One patient developed ROP up to stage 4 (partial retinal detachment), despite two laser treatments, and required a scleral buckle to stop ROP progression, and one patient reached stage 5 (complete retinal detachment), after missing the scheduled laser treatment following NICU discharge, developing bilateral retrolental fibroplasia and subsequent blindness (resulting in $0.2 \%$ overall prevalence for ROP-induced vision deficit). The mean BW and GA for all patients with some level of ROP were $1050.6 \mathrm{~g}$ (SD, 270.8) 
TABLE 1. Demographic characteristics of entire cohort for institutional crosssectional study on prevalence of ROPa in premature infants with $B W^{b} \leq 1500 \mathrm{~g}$ or $\mathrm{GA}^{\mathrm{c}} \leq 32$ weeks, Porto Alegre, Rio Grande do Sul, Brazil, 2002-2007

\begin{tabular}{|c|c|c|}
\hline & $\begin{array}{l}\text { Entire cohort } \\
\quad(n=407)\end{array}$ & Standard deviation \\
\hline \multicolumn{3}{|l|}{ Gender (No. (\%)) } \\
\hline Female & $232(57.0)$ & $N A^{d}$ \\
\hline Male & $175(43.0)$ & \\
\hline $\mathrm{SGA}^{\mathrm{e}}($ No. $(\%))$ & 252 (61.9) & NA \\
\hline BW (range) (g) & $505-2000$ & NA \\
\hline Mean BW $(\mathrm{g})$ & 1205.5 & 277.4 \\
\hline GA (range) (weeks) & $24-37$ & NA \\
\hline Mean GA (weeks) & 30.3 & 2.2 \\
\hline $\begin{array}{l}\text { a } \mathrm{ROP}=\text { retinopathy of } \\
{ }^{\mathrm{b}} \mathrm{BW}=\text { birth weight. } \\
{ }^{\mathrm{c}} \mathrm{GA}=\text { gestational age } . \\
{ }^{\mathrm{d}} \mathrm{NA}=\text { not applicable. } \\
\text { e } \mathrm{SGA}=\text { small for gesta }\end{array}$ & ntile). & \\
\hline
\end{tabular}

and 29.1 weeks (SD, 2.3), respectively (data not shown), and the mean GA for all patients with threshold (laser-treated) ROP was within the 37th week of adjusted GA. Table 3 displays the characteristics of all laser-treated patients.

\section{DISCUSSION}

The HCPA NICU has 20 intensive-care beds and is fully equipped for critical care, including pulse oximetry (for monitoring preterm infants under oxygen therapy and mechanical ventilation). During the study period, 407 VLBW premature infants survived from birth through the complete observation pe- riod (up to the 45th week of adjusted GA). The data suggest that $92.6 \%$ of all patients admitted to the HCPA NICU from the population deemed at risk for ROP were screened for the disease.

Programs to prevent ROP-induced blindness were initiated in many countries beginning in the 1980s, when the CRYO-ROP study demonstrated the first positive results from treatment of this disease with cryotherapy (13). Data from CRYO-ROP - a prospective, randomized, and multicenter study that reported ROP incidence based on a large number of patients and was conducted by well-trained, validated, and consistent examiners working under a rigor- ously designed protocol-were considered the most reliable statistics on ROP prevalence. The incidence of any stage of ROP in the CRYO-ROP study reached $65.80 \%$. Stage 3 was the most active stage of the disease (observed in $18.30 \%$ of patients). Pre-threshold ROP was found in $17.8 \%$ of the overall cohort of 4099 infants weighing less than $1251 \mathrm{~g}$ at birth, whereas threshold ROP (defined above) was found in only $6.00 \%$ (15).

Although the initial results of the Early Treatment for Retinopathy of Prematurity Cooperative Group (ET-ROP) study, published in December 2003, showed significantly better ROP outcomes than the CRYO-ROP study, after nine months of pre-threshold treatment (16), the authors of the current study, who began prospective data collection in 2002, preferred to use the classical indication for treatment (i.e., threshold ROP). This treatment indication is still used by many ophthalmologists around the world, and both options (treatment at pre-threshold and threshold ROP) are suggested in the Brazilian ROP guidelines (10).

The study by Gilbert et al. in 2005 suggested that the infant population at risk for severe ROP in highly developed countries differs from that in less developed countries (5). However, it should be noted that 1) most published data on ROP come from selected NICU series, and 2) due to the intensive care setting, these types of series are rarely validated

TABLE 2. ROPa prevalence (at $95 \% \mathrm{Cl}^{\mathrm{b}}$ ) in premature infants with $\mathrm{BW}^{\mathrm{c}} \leq 1500 \mathrm{~g}$ or $\mathrm{GA}^{\mathrm{d}} \leq 32$ weeks, by BW-differentiated group, Porto Alegre, Rio Grande do Sul, Brazil, 2002-2007

\begin{tabular}{|c|c|c|c|c|c|c|c|c|}
\hline \multirow[b]{3}{*}{ Level of ROP } & \multirow{2}{*}{\multicolumn{2}{|c|}{ Group 1}} & \multirow{2}{*}{\multicolumn{2}{|c|}{ Group 2}} & \multicolumn{2}{|c|}{ Group 3} & \multirow{2}{*}{\multicolumn{2}{|c|}{ Group 4}} \\
\hline & & & & & \multirow{2}{*}{$\begin{array}{c}\mathrm{BW}> \\
1000 \mathrm{~g} / \\
\leq 1250 \mathrm{~g} \\
\text { No. }(\%)\end{array}$} & \multirow[b]{2}{*}{$\begin{array}{l}95 \% \mathrm{Cl} \\
\text { (range) }\end{array}$} & & \\
\hline & $\begin{array}{c}\text { Entire } \\
\text { cohort } \\
\text { No. (\%) }\end{array}$ & $\begin{array}{l}95 \% \mathrm{Cl} \\
\text { (range) }\end{array}$ & $\begin{array}{c}\mathrm{BW} \leq \\
1000 \mathrm{~g} \\
\text { No. (\%) }\end{array}$ & $\begin{array}{l}95 \% \mathrm{Cl} \\
\text { (range) }\end{array}$ & & & $\begin{array}{c}\text { BW > } \\
1250 \mathrm{~g} \\
\text { No. (\%) }\end{array}$ & $\begin{array}{l}95 \% \mathrm{Cl} \\
\text { (range) }\end{array}$ \\
\hline None & $303(74.5)$ & & $51(51.5)$ & & $91(77.1)$ & & $161(84.7)$ & \\
\hline Stages $1-5$ & $104(25.5)$ & $21.5-30.0$ & $48(48.5)$ & $38.8-58.3$ & $27(22.9)$ & $16.0-31.1$ & $29(15.3)$ & $10.7-20.9$ \\
\hline 1 & 46 (11.3) & $8.5-14.7$ & $12(12.1)$ & $6.7-19.7$ & $13(11.0)$ & $6.3-17.6$ & $21(11.1)$ & $7.2-16.1$ \\
\hline 2 & $34(8.4)$ & $5.9-11.3$ & $18(18.2)$ & $11.5-26.7$ & $11(9.3)$ & $5.0-15.6$ & $5(2.6)$ & $1.0-5.7$ \\
\hline $3^{e}$ & $22(5.4)$ & $3.5-7.9$ & $16(16.2)$ & $9.9-24.4$ & $3(2.5)$ & $0.7-6.8$ & $3(1.6)$ & $0.4-4.2$ \\
\hline $4^{e}$ & $1(0.2)$ & $0.01-1.2$ & $1(1.0)$ & $0.05-4.9$ & $0(0.0)$ & $0.0-2.5$ & $0(0.0)$ & $0.0-1.6$ \\
\hline $5^{e}$ & $1(0.2)$ & $0.01-1.2$ & $1(1.0)$ & $0.05-4.9$ & $0(0.0)$ & $0.0-2.5$ & $0(0.0)$ & $0.0-1.6$ \\
\hline Total no. of patients & 407 & & 99 & & 118 & & 190 & \\
\hline
\end{tabular}


TABLE 3. Characteristics of laser-treated patients in cohort for institutional cross-sectional study on prevalence of $R O \mathrm{P}^{a}$ in premature infants with $\mathrm{BW}^{\mathrm{b}} \leq 1500 \mathrm{~g}$ or $\mathrm{GA}^{\mathrm{c}} \leq 32$ weeks, Porto Alegre, Rio Grande do Sul, Brazil, 2002-2007

\begin{tabular}{|c|c|c|c|c|c|c|c|}
\hline $\begin{array}{l}\text { Year of } \\
\text { treatment }\end{array}$ & BW & GA & Gender & $\begin{array}{l}\text { ROP } \\
\text { stage }\end{array}$ & $\begin{array}{l}\text { ROP } \\
\text { zone }^{d}\end{array}$ & $\begin{array}{c}\mathrm{GA} \\
\text { (at } \\
\text { treatment) }\end{array}$ & $\begin{array}{c}\text { Anatomical } \\
\text { outcome } \\
\text { (after laser } \\
\text { treatment) }\end{array}$ \\
\hline 2002 & 710 & 26 & $\mathrm{~F}^{\mathrm{e}}$ & $\geq 3^{f}$ & II & 36 & $\mathrm{R}^{\mathrm{g}}$ \\
\hline 2002 & 1260 & 28 & $M^{h}$ & $\geq 3$ & II & 37 & $\mathrm{R}$ \\
\hline 2003 & 635 & 27 & $\mathrm{~F}$ & $\geq 3$ & II & 36 & $\mathrm{R}$ \\
\hline 2003 & 780 & 31 & M & $\geq 3$ & II & 40 & $\mathrm{R}$ \\
\hline 2003 & 935 & 30 & M & $\geq 3$ & II & 37 & $\mathrm{R}$ \\
\hline 2003 & 1230 & 31 & M & $\geq 3$ & II & 40 & $\mathrm{R}$ \\
\hline 2004 & 625 & 26 & $\mathrm{~F}$ & $\geq 3$ & II & 36 & $\mathrm{R}$ \\
\hline 2004 & 1080 & 26 & $\mathrm{~F}$ & $\geq 3$ & II & 37 & $\mathrm{R}$ \\
\hline 2004 & 1315 & 32 & M & $\geq 3$ & II & 41 & $\mathrm{R}$ \\
\hline 2005 & 620 & 25 & $\mathrm{~F}$ & $\geq 3$ & II & 36 & $\mathrm{R}$ \\
\hline 2005 & 900 & 31 & M & $\geq 3$ & II & 40 & $\mathrm{R}$ \\
\hline 2005 & 920 & 30 & M & $\geq 3$ & II & 38 & $P^{i}$ \\
\hline 2005 & 990 & 29 & M & $\geq 3$ & II & 39 & $\mathrm{R}$ \\
\hline 2005 & 1500 & 30 & $\mathrm{~F}$ & $\geq 3$ & ॥ & 40 & $\mathrm{R}$ \\
\hline 2006 & 700 & 26 & $\mathrm{~F}$ & $\geq 3$ & II & 36 & $\mathrm{R}$ \\
\hline 2006 & 750 & 28 & $\mathrm{~F}$ & $\geq 3$ & II & 38 & $\mathrm{R}$ \\
\hline 2006 & 755 & 25 & $\mathrm{~F}$ & $\geq 3$ & II & 36 & $\mathrm{R}$ \\
\hline 2006 & 850 & 28 & $\mathrm{~F}$ & $\geq 3$ & II & 37 & $\mathrm{R}$ \\
\hline 2006 & 870 & 30 & M & $\geq 3$ & II & 40 & $\mathrm{R}$ \\
\hline 2006 & 890 & 26 & $\mathrm{~F}$ & $\geq 3$ & II & 37 & $\mathrm{R}$ \\
\hline 2006 & 1055 & 27 & $\mathrm{M}$ & $\geq 3$ & II & 39 & $\mathrm{R}$ \\
\hline 2007 & 730 & 28 & M & $\geq 3$ & II & 41 & $\mathrm{R}$ \\
\hline 2007 & 1020 & 32 & M & $\geq 3$ & II & 41 & $\mathrm{R}$ \\
\hline Mean & 918.26 & 28.35 & & & Mean & 38.17 & \\
\hline Median & 890 & 28 & & & Median & 38 & \\
\hline SD $^{j}$ & 236.86 & 2.27 & & & SD & 1.87 & \\
\hline Min & 620 & 25 & & & Min & 36 & \\
\hline Max & 1500 & 32 & & & $\operatorname{Max}$ & 41 & \\
\hline
\end{tabular}

${ }^{a} \mathrm{ROP}=$ retinopathy of prematurity.

${ }^{\mathrm{b}} \mathrm{BW}=$ birth weight

${ }^{c} \mathrm{GA}=$ gestational age.

${ }^{\mathrm{d}}$ Location of area of abnormal vascular growth on the retina (zones 1-3).

e $\mathrm{F}=$ female.

${ }^{f}$ Severe ROP (threshold stage 3 or higher) requiring treatment to prevent vision loss, as per the criteria of the U.S.-based Multicenter Trial of Cryotherapy for Retinopathy of Prematurity (CRYO-ROP). Threshold disease is defined as stage 3 ROP in zone I or II for at least five contiguous or eight total clock hours (30-degree sectors) with plus disease (dilation and tortuosity of the posterior retinal blood vessels).

g $\mathrm{R}=$ regression.

${ }^{\mathrm{h}} \mathrm{M}=$ male.

$\mathrm{P}=$ progression.

$\mathrm{SD}=$ standard deviation

in terms of population and epidemiology, especially in Brazil and other Latin American countries.

In Brazil, Graziano et al. reported retrospective institutional data from 102 preterm infants with BW $<1500 \mathrm{~g}$ (January 1992 to December 1993) that showed $29.9 \%$ had some degree of ROP (17). These data, collected from one NICU in the city of São Paulo, are similar to the study results from Porto Alegre presented here. Both sets of data were from large cities in South and Southeast Brazil, where the quality of intensive care for premature infants is excellent. An- other more recently published Brazilian study disclosed the prevalence of ROP in Joinville (another city in southern Brazil) among infants with BW $<1600 \mathrm{~g}$ or GA $<37$ weeks (i.e., outside the parameters for BW and GA stipulated in the Brazilian guidelines for ROP screening, because the study's data collection took place from 1992 to 1999, before the first ROP Workshop in 2002). The authors reported a 20\% prevalence of ROP (any stage) in their prospective cohort of 228 infants. They also reported ROP occurrence in larger infants (with $\mathrm{BW}>1600 \mathrm{~g}$ and GA $\geq 32$ weeks) (18). These data dif- fered from that obtained in the current study, which showed a mean BW and mean GA of $1050.6 \mathrm{~g}$ (SD, 270.8) and 29.1 weeks (SD, 2.3), respectively, among infants who developed ROP (data not shown), and severe ROP in only three (2.5\%) neonates with $\mathrm{BW}>1000 \mathrm{~g}$ and $\leq 1250 \mathrm{~g}$ and three $(1.6 \% ; 95 \% \mathrm{CI}, 0.4-4.2)$ infants with BW >1 $250 \mathrm{~g}$ (Table 2).

In 2001, a study conducted in India by Varughese et al. (19) found some degree of ROP in $51.89 \%$ of infants screened for the disease at a level-3 hospital in a metropolitan area of Delhi. This report called attention to the need for more ophthalmologists qualified to perform ROP screening in India. This same situation has been found in Brazil, where ROP screening programs are only available in major cities and are usually limited to university level-3 hospitals (14).

\section{Conclusion}

The overall ROP prevalence of $25.5 \%$ found in the current institutional study, and the percentage of infants diagnosed with severe disease (about $5.8 \%$ of infants with BW $\leq 1500 \mathrm{~g}$ or GA $\leq 32$ weeks-the population deemed at risk for ROP according to the Brazilian guidelines for ROP screening), were similar to the findings of other studies with a similar design. The authors of the current study believe the HCPA NICU is achieving better control by the nursery staff in their delivery of oxygen to infants under mechanical ventilation by distributing adequate information about the important role this therapy can play in decreasing the incidence of severe ROP among the neonates it delivers. As mentioned above, during the study period, only one patient developed ROP up to stage 4 (after two laser treatments) and one patient ( $0.2 \%$ of the overall cohort) progressed to stage 5 (blindness).

Although the incidence of ROP appears to be higher in North and Northeast Brazil (where ROP is still being described in infants with BW outside the recommended parameters of the Brazilian ROP screening guidelines) (20), as of the current study, which was based on institutional data, no nationwide survey has been conducted to confirm this trend. A comprehensive national study of ROP incidence is therefore recommended to verify possible regional differences in the prevalence of the disease. 


\section{REFERENCES}

1. Lermann VL, Fortes Filho JB, Procianoy RS. The prevalence of retinopathy of prematurity in very low birth weight newborn infants. J Pediatr (Rio J). 2006;82(1):27-32.

2. Gilbert C. Retinopathy of prematurity: epidemiology. J Comm Eye Health. 1997;10:22-4.

3. Gilbert C, Rahi J, Eckstein M, O'Sullivan J, Foster A. Retinopathy of prematurity in middle-income countries. Lancet. 1997;350 (9070):12-4.

4. Bancalari AM, Gonzaléz RR, Vásques CC, Pradenas IK. Retinopatía del prematuro: incidencia y factores asociados. Rev Chil Pediatr [Internet]. 2000 Mar [cited 2007 Dec 9];71(2): [about 9 p.]. Available from: http://www. scielo.cl/scielo.php?pid=S0370-41062000000 200006\&script $=$ sci arttext.

5. Gilbert C, Fielder A, Gordillo L, Quinn G, Semiglia R, Visintin $P$, et al. Characteristics of infants with severe retinopathy of prematurity in countries with low, moderate, and high levels of development: implications for screening programs. Pediatrics. 2005;115(5): e518-25. Epub 2005 Apr 1. Available from: http://pediatrics.aappublications.org/cgi/ content/abstract/115/5/e518.

6. Fortes Filho JB, Eckert GU, Procianoy L, Barros CK, Procianoy RS. Incidence and risk factors for retinopathy of prematurity in very low and in extremely low birth weight infants in a unit-based approach in southern Brazil. Eye. 2009;23(1):25-30; doi: 10.1038/sj.eye. 6702924. Epub 2007 Jul 6.

7. Charan R, Dogra MR, Gupta A, Narang A. The incidence of retinopathy of prematurity in a neonatal care unit. Indian J Ophthalmol. 1995;43(3):123-6.
8. Shah NJ. Are the Indian retinopathy of prematurity criteria appropriate for Indian babies? Indian J Ophthalmol. 2005;53(4):295.

9. Graziano RM, Leone CR. Problemas oftalmológicos mais freqüentes e desenvolvimento visual do pré-termo extremo. J Pediatr (Rio J). 2005;81(1 Supl):S95-100.

10. Zin A, Florêncio T, Fortes Filho JB, Nakanami CR, Gianini N, Graziano RM, et al. Proposta de diretrizes brasileiras do exame e tratamento de retinopatia da prematuridade (ROP). Arq Bras Oftalmol. 2007;70(5):875-83.

11. The International Classification of Retinopathy of Prematurity (ICROP). The Committee for the Classification of Retinopathy of Prematurity. Arch Ophthalmol. 1984;102(8): $1130-4$.

12. The International Classification of Retinopathy of Prematurity (ICROP). II. The classification of retinal detachment. The International Committee for the Classification of the Late Stages of Retinopathy of Prematurity. Arch Ophthalmol. 1987;105(7):906-12.

13. Multicenter Trial of Cryotherapy for Retinopathy of Prematurity (CRYO-ROP). Preliminary results. The Cryotherapy for Retinopathy of Prematurity Cooperative Group. Arch Ophthalmol. 1988;106(4):471-9.

14. Fortes Filho JB, Barros CK, da Costa MC, Procianoy RS. Results of a program for the prevention of blindness caused by retinopathy of prematurity in southern Brazil. J Pediatr (Rio J). 2007;83(3):209-16.

15. Palmer EA, Flynn JT, Hardy RJ, Phelps DL, Phillips CL, Schaffer DB, et al. Incidence and early course of retinopathy of prematurity. The Cryotherapy for Retinopathy of Prema- turity Cooperative Group. Ophthalmology. 1991;98(11):1628-40.

16. Early Treatment for Retinopathy of Prematurity Cooperative Group (ET-ROP). Revised indications for the treatment of retinopathy of prematurity: results of the early treatment for retinopathy of prematurity randomized trial. Arch Ophthalmol. 2003;121(12):1684-96.

17. Graziano RM, Leone CR, Cunha SL, Pinheiro AC. Prevalencia da retinopatia da prematuridade em recem-nascidos de muito baixo peso. J Pediatr (Rio J). 1997;73(6):377-82.

18. Bonotto LB, Moreira AT, Carvalho DS. Prevalência de retinopatia da prematuridade em prematuros atendidos no período de 1992 1999 em Joinville (SC): avaliação de riscos associados-"screening." Arq Bras Oftalmol. 2007;70(1):55-61.

19. Varughese S, Jain S, Gupta N, Singh S, Tyagi V, Puliyel JM. Magnitude of the problem of retinopathy of prematurity. Experience in a large maternity unit with a medium size level-3 nursery. Indian J Ophthalmol. 2001; 49(3):187-8.

20. Veloso ACG, Gonçalves JOR, Liarth JCS, Lima HDM, Gonçalves SMHR. Retinopatia da prematuridade-estudo epidemiológico de 1003 pacientes. Arq Bras Oftalmol. 2005;68(4 Supl): S58.

Manuscript received on 17 June 2008. Revised version accepted for publication on 17 December 2008.

RESUMEN Objetivo. La retinopatía del prematuro (RP) es la principal causa de ceguera infantil en la mayoría de los países desarrollados. El objetivo de este estudio fue verificar la prevalencia de esta afección en todos los niños prematuros de muy bajo peso al nacer ingresaPrevalencia de retinopatía
del prematuro: estudio
transversal institucional de
niños prematuros en Brasil dos en un hospital docente de tercer nivel de Porto Alegre, Rio Grande do Sul, Brasil.

Métodos. Estudio transversal institucional de 407 niños prematuros que nacieron entre 2002 y 2007 con un peso de 1500 g o menos, o 32 semanas de edad gestacional o menos. Todos los niños tamizados para RP se examinaron después de la cuarta semana de vida y tuvieron seguimiento hasta la semana 45 de edad gestacional ajustada. La prevalencia de RP se estimó con un intervalo de confianza de $95 \%$.

Resultados. De los niños tamizados, 104 (25,5\%) presentaron algún grado de RP en uno o ambos ojos, mientras $24(5,8 \%)$ presentaron RP grave (estadio 3 o mayor; requerían de tratamiento para evitar la pérdida de la visión, según los criterios del Estudio Multicéntrico de Crioterapia para la Retinopatía del Prematuro, CRYO-ROP, realizado en los Estados Unidos de América). Según los criterios de la Clasificación Internacional de la Retinopatía del Prematuro (ICROP, 1984/1987), la enfermedad alcanzó los estadios 1, 2 y 3 en $46(11,3 \%), 34(8,4 \%)$ y 22 (5,4\%) niños, respectivamente. Un niño desarrolló la enfermedad hasta el estadio 4 (desprendimiento parcial de la retina) y uno alcanzó el estadio 5 (desprendimiento completo de la retina), lo que representó una prevalencia general de ceguera por RP de $0,2 \%$.

Conclusiones. La incidencia general de RP en este estudio institucional $(25,5 \%)$ es similar a los resultados obtenidos en países desarrollados. Se recomienda realizar una encuesta exhaustiva nacional sobre RP en Brasil para determinar si existe alguna diferencia regional en la prevalencia de esta enfermedad.

Palabras clave Ceguera, prevención y control; retinopatía de la prematuridad, epidemiología; prevalencia; Brasil. 